Chilly Climate for Women of Color among White Women in the Academic World.

The evening plenary session on "Democratization" was, as usual, an occasion for males to be in the spotlight.

\section{New Officers Elected: Shklar Passes Gavel to Lowi}

At the APSA 1990 Annual Business Meeting, held September 2, 1990 in San Francisco, Judith Shklar, Harvard University, presided over the election of new Association officers, and at the end of the meeting passed the gavel to Theodore J. Lowi to begin his term as Association president.

William J. Daniels, Union College, Gerhard Loewenberg, University of lowa, and Kenneth Prewitt, Rockefeller Foundation, were elected Vicepresidents for 1990-91. Charles Lipson, University of Chicago, was elected Secretary. David Brady, Stanford University, is currently serving a two-year term as Treasurer.

Eight new council members were also elected at the business meeting. Joining the Council for two-year terms are Thomas Cronin, Colorado College; Rodolfo O. de la Garza, University of Texas; Jean Bethke Elshtain, Vanderbilt University; Joanne Gowa, University of Pennsylvania; Virginia $H$. Gray, University of Minnesota; Nolan Jones, National

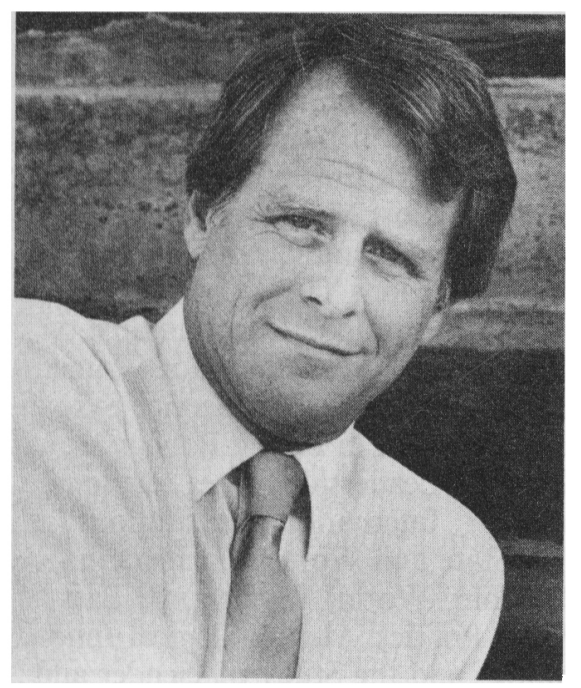

Theodore J. Lowi
Governors Association; Ruth S.

Jones, Arizona State University; and Ian Lustick, Dartmouth College.

James Q. Wilson, University of California, Los Angeles, was elected President-elect of the Association. $\mathrm{He}$ will assume the office of the President in 1991-92.

\section{James Q. Wilson Receives 1990 James Madison Award}

James Q. Wilson of the University of California, Los Angeles, was presented with the James Madison Award at the Presentation of Awards Ceremony of the Annual Meeting, August 30, 1990. The James Madison award is presented triennially to recognize a career of scholarly ex-

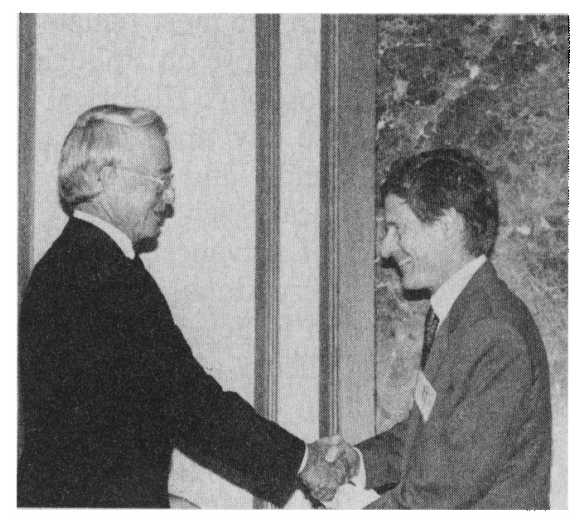

James Q. Wilson (left) receives the Madison Award from Harvey C. Mansfield, Jr., chair of the selection committee.

cellence and is considered one of the premier honors in the discipline. Professor Wilson delivered the James Madison Lecture earlier in the evening.

David E. Price, member of the U.S. House of Representatives from North Carolina, was awarded the Hubert H. Humphrey Award in recognition of notable public service by a political scientist, and Frederick Mosher, University of Virginia, was recognized posthumously with the John Gauss award which honors a lifetime of exemplary scholarship in the joint tradition of political science and public administration.

Book awards were presented to seven scholars for works published in 1989. Clarence N. Stone, University of Maryland, received the Ralph J.

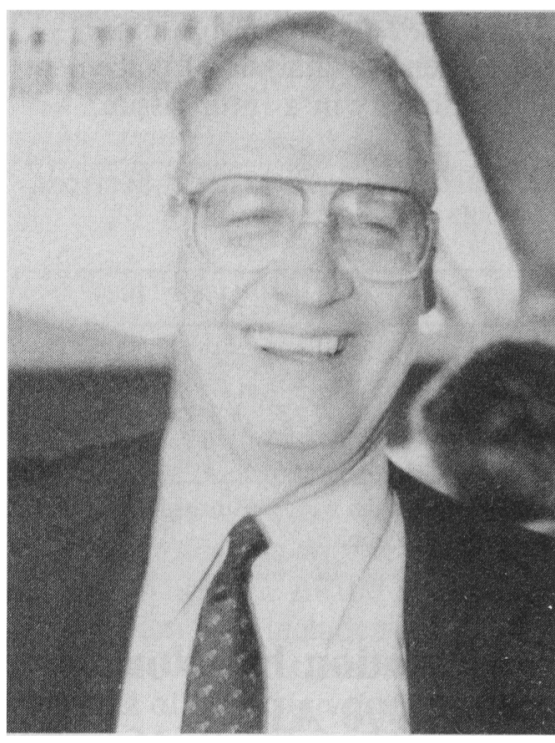

Clarence Stone

Bunche Award for the best scholarly work exploring the phenomenon of ethnic and cultural pluralism for his study Regime Politics: Governing Atlanta, 1946-1988, published by the University Press of Kansas.

The Gladys M. Kammerer Award for the best publication in the field of U.S. national policy was presented to Donald Alexander Downs, University of Wisconsin, for his study The New Politics of Pornography, published by the University of Chicago Press, and to Edward G. Carmines, Indiana University, and James A. Stimson, University of Iowa, for their work Issue Evolution: Race and the Transformation of American Politics, published by Princeton University Press.

The Victoria Schuck Award for the best book on women and politics was presented to Susan Moller Okin, Brandeis University, for Justice, Gender, and the Family, published by Basic Books, and to Judith $\mathrm{H}$.

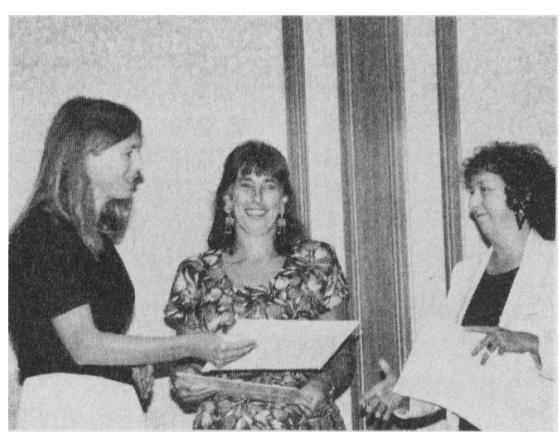

Susan Moller Okin (left), and Judith Stiehm (center), receive the Victoria Schuck Award from Nancy Hartsock. 